Jurnal Ilmiah Ibnu Sina, 6(2), Oktober 2021, 341-349

p-ISSN: 2502-647X; e-ISSN: 2503-1902

\title{
AKTIVITAS FRAKSI ETIL ASETAT KULIT BUAH JERUK NIPIS (Citrus aurantifolia (Christ) Swing) SEBAGAI ANTIPIRETIK PADA MENCIT YANG DIINDUKSI VAKSIN DPT
}

\author{
Satrio Wibowo Rahmatullah*, Eka Fitri Susiani, M. Reza Pahlevi, Guntur \\ Kurniawan, Siti Nurhaliza Leyla \\ Sekolah Tinggi Ilmu Kesehatan Borneo Lestari \\ Email: satriowibowo@stikesborneolestari.ac.id
}

Artikel diterima: 26 Agustus 2021; Disetujui: 27 September 2021

DOI: https://doi.org/10.36387/jiis.v6i2.740

\begin{abstract}
ABSTRAK
Jeruk nipis (Citrus aurantifolia (Christm.) Swing) mengandung senyawa yang bermanfaat sehingga banyak digunakan dalam pengobatan tradisional. Penelitian ini bertujuan untuk mengetahui aktivitas antipiretik dari fraksi etil asetat kulit buah jeruk nipis. Hasil uji skrining fitokimia fraksi etil asetat kulit buah jeruk nipis mengandung senyawa flavonoid, saponin, alkaloid dan minyak atsiri. Sebanyak 25 ekor mencit dibagi menjadi 5 kelompok, kelompok I kontrol negatif, kelompok II kontrol positif, kelompok III, IV, V diberikan fraksi etil asetat dosis $0,07 \% / 20 \mathrm{gBB}, 0,105 \% / 20 \mathrm{gBB}$ dan 0,14 $\% / 20 \mathrm{gBB}$. Berdasarkan hasil grafik rata-rata penurunan suhu bahwa ketiga dosis tersebut memiliki aktivitas antipiretik karena dapat menurunkan suhu dan penurunan suhu terbesar pada dosis $0,14 \% / 20 \mathrm{gBB}$. Berdasarkan hasil uji ANOVA diperoleh nilai sig. 0,000 yang berarti terdapat perbedaan suhu yang bermakna antar 5 kelompok perlakuan. Dan pada uji Independent Sample Ttest antara kontrol positif dengan dosis $0,14 \% / 20 \mathrm{gBB}$ menghasilkan nilai sig. $0,601(>0,05)$ yang berarti tidak terdapat perbedaan bermakna.
\end{abstract}

Kata kunci: fraksi etil asetat, kulit buah jeruk nipis, Citrus aurantifolia (Chrstm.) Swing, antipiretik.

\begin{abstract}
Lime (Citrus aurantifolia (Christm.) Swing) is one of the types of oranges containing elements of compounds that are beneficial, so widely used as traditional medicine. This research aims to know the antipyretic activity of ethyl acetate fraction peel of lime. Phytochemical screening test result fraction ethyl acetate lemon rind contains flavonoids, saponins, alkaloids and essential oils. Total of 25 mice were divided into 5 groups, group I negative control, group II positive control, group III,IV,V were given ethyl acetate fraction at a dose of $0,07 \% / \mathrm{gBW}, 0,105 \% / \mathrm{gBW}$ and $0,14 \% / \mathrm{gBW}$. Based on the results of graph average temperatures decrease the dose that the third has antipyretic activity because it can lower the temperature and the largest decreased in temperature at a dose $0,14 \% / g B W$. Based on the test result ANOVA obtained sig. value 0,000. which means there is a temperature
\end{abstract}


Jurnal Ilmiah Ibnu Sina, 6(2), Oktober 2021, 341-349

p-ISSN: 2502-647X; e-ISSN: 2503-1902

difference of meaning between 5 group treatment. And on Independent Test Sample T-test between a positive control with a dose $0,14 \% / \mathrm{gBW}$ the value of sig. 0,601 (>0,05) which means there is no meaningful difference.

Key words: Ethyl acetate fraction, lime rind, Citrus aurantifolia (Chrstm.) Swing, antipiretic

\section{PENDAHULUAN}

Demam merupakan penyakit yang sering dialami oleh masyarakat. Demam dapat diartikan sebagai kelainan pada sistem pengaturan suhu tubuh, sehingga suhu tubuh meningkat dibandingkan suhu tubuh normal. Suhu tubuh normal berkisar antara $36,5-37,2^{\circ} \mathrm{C}$ (Widyasari \& Ratika, 2017). Antipiretik adalah senyawa yang dapat menurunkan demam (suhu tubuh tinggi) (Tjay \& Rahardja, 2015). Antipiretik merupakan salah satu obat yang secara luas paling banyak digunakan. Obat yang biasa digunakan untuk menurunkan demam adalah parasetamol. Sekitar 175 juta tablet parasetamol dikonsumsi masyarakat Indonesia setiap tahunnya ketika gejala demam muncul karena cukup aman, mudah didapat dan harganya terjangkau (Elly, 2010). Obat ini dapat menurunkan suhu tubuh hanya pada keadaan demam, namun pemakaian obat golongan ini tidak boleh digunakan dalam jangka panjang karena bersifat toksik. Efek samping yang sering ditimbulkan setelah penggunaan antipiretik adalah respon hemodinamik seperti hipotensi, gangguan fungsi hepar dan ginjal, oliguria (kondisi dimana jumlah urin sedikit), serta retensi garam dan air (Hammond \& Boyle, 2011). Menurut Nogata dkk., (2014) jus butiran daging buahnya memiliki kandungan flavonoid yang lebih rendah dibandingkan pada kulitnya. Berdasarkan skrinning fitokimia fraksi etil asetat kulit buah jeruk nipis ( $C$. aurantifolia) mengandung golongan senyawa flavonoid, alkaloid dan saponin. Selain itu kulit jeruk nipis juga mengandung golongan senyawa minyak atsiri.

Beberapa peneliti menyatakan bahwa senyawa yang memiliki efek antipiretik adalah 
Jurnal Ilmiah Ibnu Sina, 6(2), Oktober 2021, 341-349

p-ISSN: 2502-647X; e-ISSN: 2503-1902

flavonoid, saponin (Ashfaq dkk., dengan No. 68/KEPK-FK 2016), alkaloid (Sajeesh dkk., 2011) dan minyak atsiri (Ravendra dkk., 2017). Flavonoid, alkaloid dan saponin telah menunjukkan aksi penghambatan pada enzim siklooksigenase dan sebagai hasilnya menghasilkan aktivitas antipiretik (Maina dkk., 2015).

Berdasarkan uraian tersebut, maka perlu dilakukan penelitian lebih lanjut terkait aktivitas fraksi etil asetat kulit buah jeruk nipis sebagai antipiretik pada mencit yang diinduksi vaksin DPT. Vaksin DPT digunakan sebagai induksi karena dapat meningkatkan suhu tubuh mencit secara signifikan.

\section{METODE PENELITIAN}

Penelitian ini dilakukan di Laboratorium Bahan Alam, Farmakologi-Toksikologi STIKES Borneo Lestari Banjarbaru. Determinasi tumbuhan jeruk nipis dilakukan di Laboratorium Dasar FMIPA Universitas Lambung Mangkurat dan Pembuatan Ethical Clearence dilakukan di Komite Etik Fakultas Kedokteran dan Kesehatan Universitas Lambung Mangkurat

UNLAM/EC/III/2019.

Penelitian ini dilakukan kepada 5 kelompok hewan uji (masing-masing kelompok terdiri dari 5 hewan uji) yang diberikan fraksi etil asetat kulit buah jeruk nipis dengan 3 konsentrasi berbeda, serta menggunakan kelompok kontrol positif dan negatif. konsentrasi fraksi etil asetat kulit buah jeruk nipis yang digunakan adalah sebesar 0,07 $\% / 20 \mathrm{gBB}, 0,105 \% / 20 \mathrm{gBB}, 0,14$ $\% / 20 \mathrm{gBB}$. Kontrol positif yang digunakan adalah parasetamol, sedangkan untuk kontrol negatif yang dignakan adalah Na-CMC dengan konsentrasi 0,5\%. Sebelum dilakukan pengujian fraksi etil asetat kulit buah jeruk nipis kepada hewan uji, dilakukan pengujian skrining fitokimia (uji flavonoid, saponin, steroid, triterpenoid, dan alkaloid). Proses ekstraksi menggunakan metode maserasi serta fraksinasi dengan metode ECC (Ekstraksi Cair-Cair).

Data yang diperoleh dianalisis dengan SPSS untuk mengetahui homogenitas dan normalitasnya. 
Jurnal Ilmiah Ibnu Sina, 6(2), Oktober 2021, 341-349

p-ISSN: 2502-647X; e-ISSN: 2503-1902

Untuk uji normalitasnya digunakan uji Saphiro-wilk karena sampel kurang dari 50, sedangkan untuk uji homogenitasnya digunakan uji Levene. Apabila data terdistribusi normal dan homogen dilanjutkan dengan uji parametric ANOVA. Apabila data tidak terdistribusi normal dan tidak homogen maka dilanjutkan dengan uji non parametric Kruskal-wallis, dan apabila hanya salah satu juga dilanjutkan dengan uji non parametric Kruskal-wallis. Data dikatakan homogen atau terdistribusi normal jika nilai signifikan lebih dari 0,05. Dan juga digunakan uji Independent Sample T-test untuk mengetahui aktivitas yang lebih bagus dari dosis yang diberikan.

\section{HASIL DAN PEMBAHASAN}

Fraksinasi adalah pemisahan antara senyawa yang diinginkan dengan senyawa lain yang masih terkandung dalam simplisia tersebut berdasarkan tingkat kepolaran, senyawa yang diperoleh lebih murni dibanding ekstraksi (Septiarusli dkk., 2012). Oleh karena itu, peneliti menggunakan metode fraksinasi.

$$
\text { Berdasarkan penelitian }
$$

Syamsi \& Angelia (2019) menyatakan bahwa ekstrak etanol 96\% jeruk nipis memiliki efek antipiretik terhadap mencit yang telah diinduksi demam dengan vaksin DPT.

Kulit buah jeruk nipis ( $C$. Aurantifolia) segar diproses sampai didapatkan simplisia kering. Hasil rendemen simplisia yang diperoleh yaitu $38,46 \%$. Serbuk simplisia yang sebelumnya telah diayak kemudian diekstraksi secara maserasi dengan etanol 96\% (1:4) selama 1x24 jam, dan dilakukan $2 \mathrm{x}$ remaserasi didapatkan rendemen ekstrak sebesar $10,48 \%$. Penyerbukan simplisia dapat meningkatkan luas permukaan partikel yang dapat masuk ke dalam serbuk dan akan mengeluarkan zat kimia yang akan bercampur dengan zat penyari sehingga proses penyarian dapat berlangsung efektif. Kemudian diayak menggunakan ayakan mesh 40. Tujuan dari pengayakan adalah untuk menyeragamkan ukuran serbuk. Serbuk simplisia kemudian disimpan dalam wadah tertutup 
Jurnal Ilmiah Ibnu Sina, 6(2), Oktober 2021, 341-349

p-ISSN: 2502-647X; e-ISSN: 2503-1902

rapat.Proses dilanjutkan dengan

bervariasi antar kelompok

fraksinasi secara ECC (Ekstraksi

perlakuan. Kelompok kontrol

Cair-Cair) hingga didapatkan negatif yang diberi larutan $\mathrm{Na}-$ rendemen fraksi etil asetat sebanyak CMC 0,5\% merupakan kelompok 5,6\%. Hasil skrining fitokimia dari fraksi etil asetat kulit buah jeruk nipis mengandung flavonoid, alkaloid, saponin, dan minyak atsiri.

Berdasarkan uji aktivitas antipiretik fraksi etil asetat kulit buah jeruk nipis, diperoleh hasil yang digambarkan dalam grafik yang dapat dilihat pada Gambar 1. yang paling kecil mengalami penurunan suhu dibandingkan kelompok perlakuan lainnya. Hal ini disebabkan karena larutan $\mathrm{Na}$ CMC $0,5 \%$ tidak memiliki efek antipiretik. Kelompok perlakuan kontrol positif yang diberi paracetamol mengalami penurunan suhu terbesar pada hewan uji, yaitu

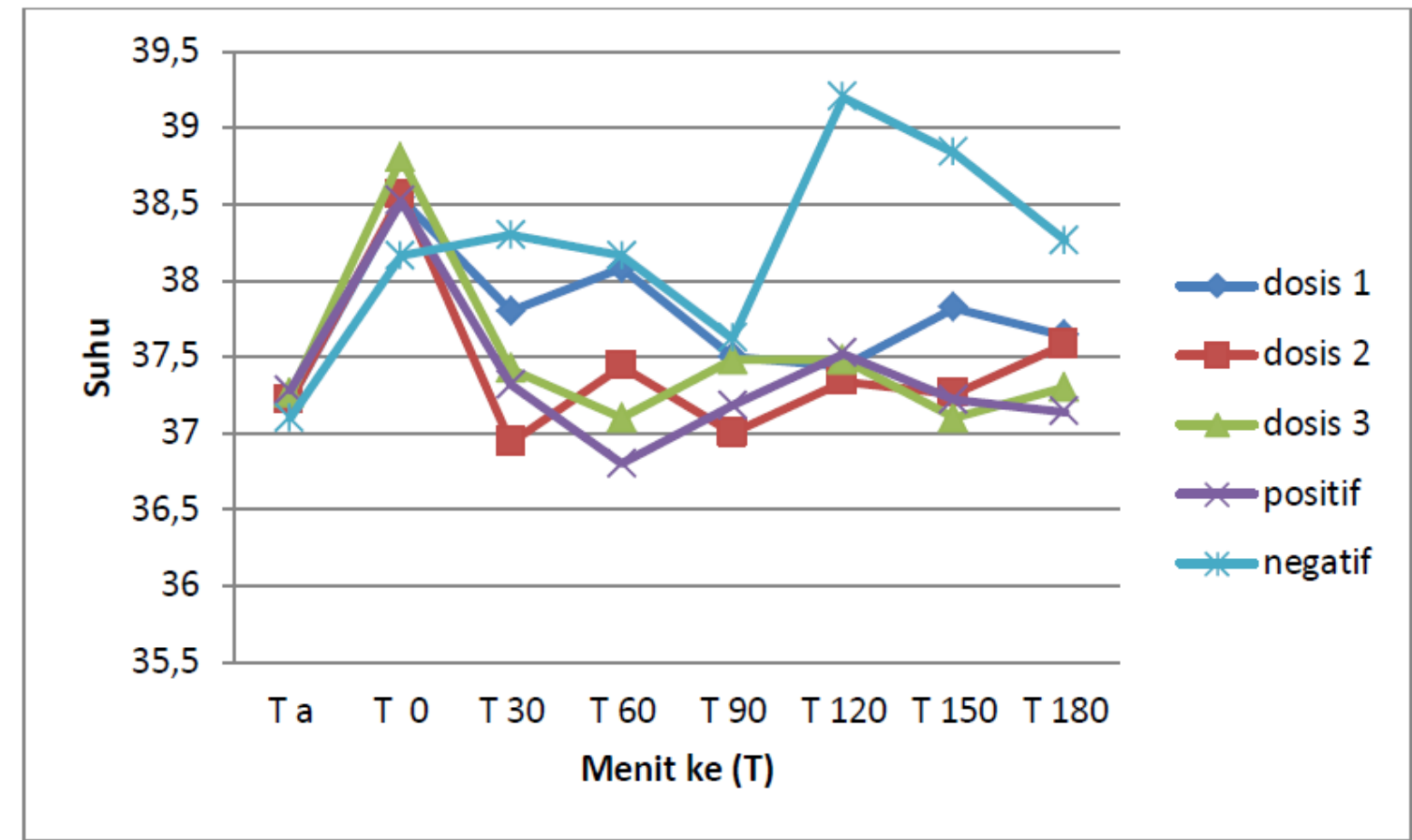

Gambar 1. Grafik Rata-rata

Pengukuran Suhu Rektal Mencit

Hasil penelitian ini menunjukkan penurunan suhu yang $\leq 37,5^{\circ} \mathrm{C}$. Penurunan suhu yang besar terjadi karena paracetamol memiliki efek antipiretik. Antipiretik mencegah pembentukan prostaglandin dengan jalan 
Jurnal Ilmiah Ibnu Sina, 6(2), Oktober 2021, 341-349

p-ISSN: 2502-647X; e-ISSN: 2503-1902

menghambat

enzim

siklooksigenase

(Hastuti \&

Endrawati, 2016). Penggunaan paracetamol sebagai kontrol positif karena paracetamol merupakan antipiretik yang secara umum dipakai di masyarakat dan mudah didapat.

Kelompok fraksi etil asetat kulit buah jeruk nipis dosis 1 mengalami penurunan suhu, yaitu $<38^{\circ} \mathrm{C}$. Kelompok dosis 1 memiliki efek antipiretik namun belum efektif karena penurunan suhu yang terjadi masih lebih kecil dibandingkan dengan kelompok kontrol positif yang diberikan parasetamol. Pada kelompok fraksi etil asetat kulit buah jeruk nipis dosis 2 mengalami penurunan suhu yang besar, yaitu $\leq 37,5^{\circ} \mathrm{C}$. Sedangkan pada kelompok fraksi etil asetat kulit buah jeruk nipis dosis 3 juga mengalami penurunan suhu yang besar, yaitu $<37,5^{\circ} \mathrm{C}$. Penurunan suhu pada kelompok fraksi etil asetat kulit buah jeruk nipis dosis 1, 2 dan 3 mulai terjadi pada hewan uji di menit ke-30. Namun pada menit ke-60 dosis 1 dan dosis 2 mengalami kenaikan suhu, sedangkan dosis 3 mengalami penurunan suhu. Dan pada menit ke-180 dosis 3 mengalami penurunan suhu paling besar dibanding dosis 1 dan 2 . Dilihat pada grafik bahwa kelompok fraksi etil asetat kulit buah jeruk nipis dosis 3 terjadi penurunan suhu yang besar melebihi penurunan suhu yang tejadi pada kelompok fraksi etil asetat kulit buah jeruk nipis dosis 1 dan 2, dan juga terlihat sebanding dengan penurunan suhu kelompok paracetamol.

Dilihat pada grafik rata-rata pengukuran suhu rektal mencit data yang diperoleh menunjukkan adanya variasi penurunan suhu pada tiap kelompok perlakuan. Menurut Putra dkk. (2015) penurunan yang bervariasi ini disebabkan oleh banyak faktor yang mempengaruhi seperti hormon, lingkungan, kondisi lambung, dan dapat pula disebabkan oleh faktor psikologis seperti stress yang dialami akibat pengukuran berulang pada rektum mencit.

Kemudian data dianalisis 
Jurnal Ilmiah Ibnu Sina, 6(2), Oktober 2021, 341-349

p-ISSN: 2502-647X; e-ISSN: 2503-1902

dengan SPSS untuk mengetahui homogenitas dan normalitasnya. Untuk uji normalitasnya digunakan uji Saphiro-wilk. Berdasarkan hasil dari uji Shapiro-Wilk nilai signifikan dari 5 kelompok perlakuan adalah > 0,05 maka dapat disimpulkan bahwa data terdistribusi normal. Kemudian dilakukan uji Levene yang ditujukan untuk melihat dan mengetahui homogenitas pada sebaran data yang diperoleh.

Berdasarkan hasil dari uji Levene, nilai signifikan yang diperoleh adalah 0,147 yang berarti $>0,05$ maka dapat disimpulkan bahwa data yang dihasilkan homogen. Karena data yang dihasilkan terdistribusi normal dan homogen, maka uji selanjutnya yang digunakan adalah uji parametrik yaitu uji Analysis of Variance (ANOVA) untuk melihat dan mengetahui data yang diperoleh terdapat perbedaan yang bermakna atau tidak terdapat perbedaan yang bermakna. Berdasarkan hasil dari uji Analysis of Variance (ANOVA), diperoleh hasil signifikan 0,000 yang dapat disimpulkan bahwa terdapat perbedaan suhu yang bermakna dari 5 kelompok perlakuan.

Kemudian uji selanjutnya yang dilakukan adalah uji Independen T-Test untuk melihat perbandingan antar 2 kelompok perlakuan. Pengujian dilakukan sebanyak dua kali yaitu pada perlakuan kontrol positif dengan dosis 3 dan kontrol negatif dengan dosis 3. Dosis 3 digunakan karena dilihat pada grafik bahwa dosis 3 yang menurunkan suhu paling besar. Berdasarkan hasil dari uji Independen T-Test antara kontrol positif dengan dosis 3 diperoleh nilai signifikan 0,601 $(>0,05)$. Hal tersebut dapat disimpulkan bahwa tidak terdapat perbedaan yang bermakna antara suhu yang dihasilkan oleh dosis 3 dengan suhu yang dihasilkan oleh kontrol positif yaitu paracetamol. Sedangkan hasil dari uji Independen $\mathrm{T}$-Test antara kontrol negatif dengan dosis 3 memperoleh sig 0,001 $(<0,05)$. Sehingga dapat disimpulkan bahwa terdapat perbedaan yang bermakna antara suhu yang dihasilkan oleh dosis 3 
Jurnal Ilmiah Ibnu Sina, 6(2), Oktober 2021, 341-349

p-ISSN: 2502-647X; e-ISSN: 2503-1902

dengan suhu yang dihasilkan oleh kontrol negatif yaitu Na-CMC.

\section{KESIMPULAN}

Berdasarkan hasil penelitian ini dapat disimpulkan bahwa fraksi etil asetat kulit buah jeruk nipis memiliki aktivitas antipiretik pada mencit jantan yang diinduksi vaksin DPT. Fraksi etil asetat dosis 3 (dosis $0,14 \% / 20 \mathrm{gBB})$ merupakan dosis yang mampu memberikan aktivitas antipiretik terbaik dilihat dari kemampuannya dalam menurunkan suhu yang tidak berbeda bermakna jika dibandingkan dengan kelompok kontrol positif.

\section{UCAPAN TERIMA KASIH}

Peneliti mengucapkan terima kasih yang sebesar-besarnya kepada semua pihak yang telah membantu, terutama kepada Yayasan Borneo Lestari yang telah memfasilitasi baik dukungan finansial maupun dukungan sarana prasarana lainnya dalam penelitian internal dosen STIKES Borneo Lestari.

\section{DAFTAR PUSTAKA}

Ashfaq, K., B.A. Choudhary, M. Uzair, S.N. Hussain, M.A. Ghaffari, W. Sarwar.M. Manzoor. 2016. Antipyretic, Analgesic and Antiinflammatory Activities of Methanol Extract of Root Bark of Acaci Jacquemontii Benth (Fabaceae) in Experimental Animals. Tropical Journal of Pharmaceutical Research. 15(9): 1859-1863.

Elly, F.E. 2010. Efek Antipiretik Ekstrak Daun Pare (Momordica charantia I.) Pada Tikus Putih Jantan. Skripsi. Program Sarjana, Universitas Sebelas Maret, Surakarta.

Hammond N.E. \& Boyle M. 2011. Pharmacological Versus Non Pharmacological Antipyretic Treatments In Febrile Critically Ill Adult Patients: A Systematic Review and Meta-Analysis. Australian Critical Care. 24(1): 4-17.

Hastuti S. \& S. Endrawati. 2016. Aktivitas Antipiretik Ekstrak Etil Asetat Daun Seligi (Phyllanthus buxifolius Muell.Arg) Pada Mencit Jantan Galur Swiss. Jurnal Biologi Papua. 8(1): 1-6.

Maina, G.S, M.B. Maina, N.J. Muriithi, M.J. Kiambi, J.K. Kelvin, A. Umar, M.K. John, N.W. Ann, N.M. Piero, M.N. David. 2015. Antipyretic Properties of Dichloromethane: Methanolic Leaf and Root Bark Extracts of Carissa edulis in Rats. Asian Journal of Biomedical 
Jurnal Ilmiah Ibnu Sina, 6(2), Oktober 2021, 341-349

p-ISSN: 2502-647X; e-ISSN: 2503-1902

and Pharmaceutical Sciences. 5(43): 12-20.

Nogata, Y., K. Sakamoto, H. Shiratsuchi, T. Ishii, M. Yano, H. Ohta. 2014. Flavonoid Composition of Fruit Tissues of Citrus Species. Bioscience, Biotechnology, and Biochemistry. 70(1): 178-192.

Putra, M.P., S. B. Rahmah, M. Kusmiati. 2015.

Perbandingan Efektifitas Antipiretik Antara Ekstrak Etanol Kunyit Putih (Curcuma zedoaria Rosc) dengan Parasetamol pada Tikus Model Demam. Prosiding Pendidikan Dokter. Fakultas Kedokteran Universitas Islam Bandung. 1(2).

Ravendra, K., P. Om, P. Anil K, K. Mahesh, I. Valary A, S. Lech. 2017. Chemical Composition and Anti-inflamatory, Antinociceptive and Antipyretic Activity of Rhizome Essential Oil of Globba sessiliflora Sims. Collected From Garhwal Region of Uttarakhand. Journal of Herbal Drugs. 8(1): 59-69.

Sajeesh, T., K. Arunachalam, T. Parimelazhagan. 2011.
Antioxidant and Antipyretic Studies on Pothos scandens L. Asian Pacific Journal of Tropical Medicine. 889-899.

Septiarusli, I.E., K. Haetami, Y. Mulyani, D. Dono. 2012. Potensi Senyawa Metabolit Sekunder Dari Ekstrak Biji Buah Keben (Barringtonia asiatica) Dalam proses Anestesi Ikan Kerapu Macan (Ephinephelus fuscoguttatus). Jurnal Perikanan dan Kelautan. 3(3): 295-299.

Syamsi, N. \& A. Andilolo. 2019. Efek Antipiretik Ekstrak Jeruk Nipis (Fructus Citrus aurantifolium) Pada Mencit (Mus musculus). Jurnal Kesehatan Tadulako. 5 (1).

Tjay, T. H. \& K. Rahardja. 2015. Obat-obat Penting, Khasiat, Penggunaan, dan Efek Sampingnya. PT. Elex Media Komputindo, Jakarta.

Widyasari, R. \& R. Ratiningsih. 2017. Uji Aktivitas Antipiretik Ekstrak Etanol Kulit Jeruk Manis (Citrus $x$ aurantium L) Terhadap Tikus Putih (Rattus novergicus) Jantan Galur Wistar Yang Diinduksi Pepton 5\%. 